\title{
Egészségügyi szakdolgozók mentális zavarokkal kapcsolatos ismereteinek és a betegekkel szembeni attitüdjének vizsgálata
}

\author{
Ács Andrea ${ }^{1,2}$ - Mészáros Judit dr. - Balogh Zoltán dr. ${ }^{1}$ \\ ${ }^{1}$ Semmelweis Egyetem, Egészségtudományi Kar, Budapest \\ ${ }^{2}$ Semmelweis Egyetem, Rácz Károly Doktori Iskola, Budapest
}

\begin{abstract}
Bevezetés: A mentális betegek stigmatizációja mind a hazai, mind a nemzetközi kutatásokban kiemelt jelentőséggel bír. Az érintetteknek a társadalmi elóitéleteken túl az egészségügyi szakemberek stigmatizáló attitúdjével is meg kell küzdeniük.

Célkitüzés: A vizsgálat során a pszichiátriai betegségekkel kapcsolatos sztereotípiák, a stigmatizáló egészségügyi szakdolgozói attitüdök jelenlétét kerestük. Célunk volt továbbá az ápolási munkát végző dolgozók körében a mentális betegségekkel kapcsolatos ismeretek felmérése. Az eredmények tükrében az ápolóképzések reformjával kapcsolatos javaslatok tételét tűztük ki célul.

Módszer: A Magyar Egészségügyi Szakdolgozói Kamara (mentésügyi, sürgősségi betegellátási, pszichiátriai ápolási és felnőttápolási tagozat) tagjainak körében végzett online, kvantitatív, kérdőíves felmérés eredményeinek deskriptív és többváltozós elemzése.

Eredmények: A kitöltött kérdőívek közül 495 volt értékelhető ( $\mathrm{n}=495)$. A pszichiátrián dolgozó ápolókat kevésbé stigmatizáló attitúd jellemzi a mentés és a sürgősségi ellátás, illetve az egyéb területeken dolgozókénál. Erőteljesebben megjelenik a stigmatizáló attitúd a hosszabb ideje a szakmában tevékenykedőknél. Kevésbé stigmatizáló attitúd jellemzi a föiskolai vagy egyetemi végzettségúeket, mint a középfokú végzettségúeket. A vizsgálatban részt vevő összes ápoló közel fele (47\%) tartja hiányosnak felkészültségét a mentális betegségekkel kapcsolatosan. Tagozati bontásban a mentés és a sürgősségi ellátás dolgozóinál $49 \%$, a felnőttápolási tagozat tagjainál $55 \%$ ez az arány. A pszichiátriai ápolók körében is viszonylag nagy $(28 \%)$ azok aránya, akik hiányosnak ítélik meg felkészültségüket, ugyanakkor természetesen a megfelelő felkészültséget is ez a csoport választotta a legnagyobb arányban (37\%).

Következtetés: A pszichiátria oktatását az ápolóképzések minden szintjén szükséges hatékonyabbá tenni. Fontos lenne továbbá az érzékenyítő, stigma elleni módszerek beépítése és az empátia fejlesztése.

Orv Hetil. 2020; 161(2): 56-66.
\end{abstract}

Kulcsszavak: mentális beteg, ápoló, stigma, attitúd, ápolóképzés

\section{Examining health professionals' knowledge and attitudes towards mental disorders}

Introduction: The stigmatization of mental patients is a priority topic in both domestic and international research. In addition to social prejudices, people living with mental illness must also struggle with the stigmatizing attitude of health professionals.

Aim: It was a survey of attitudes of nursing health care professionals towards psychiatric patients and mental illnesses. We also aimed to assess mental health knowledge among the nursing staff. In the light of the results, our aim was to make proposals for the reform of nursing education.

Method: We performed the survey among members of the Hungarian Chamber of Health Care Professionals, in 4 sections (paramedics, emergency nurses, psychiatric nurses and adult nurses). We analyzed the results of the online quantitative survey with multiple variables descriptively.

Results: 495 of the completed questionnaires were evaluable $(n=495)$. Psychiatric nurses are characterized by a less stigmatizing attitude towards rescue and emergency carers and other adult nurses. Less stigmatizing attitudes are characterized by BSc and MSc graduates than those who have secondary education. Almost half of all nurses (47\%) 
in the study feel they have a lack of preparedness about mental illnesses. The rate is $49 \%$ for rescue and emergency workers, and $55 \%$ for members of the adult care section. There is also a relatively high proportion (28\%) of psychiatric nurses, who consider their skills to be inadequate. At the same time, of course, this group replied in the highest proportion (37\%) that his knowledge is adequate.

Conclusion: Psychiatric education should be made more effective at all levels of nursing training. It would also be important to incorporate sensitizing and anti-stigma methods and to develope empathy.

Keywords: mental patient, nurse, stigma, attitude, nursing education

Ács A, Mészáros J, Balogh Z. [Examining health professionals' knowledge and attitudes towards mental disorders]. Orv Hetil. 2020; 161(2): 56-66.

(Beérkezett: 2019. július 11.; elfogadva: 2019. augusztus 29.)

\section{Rövidítések}

ANOVA $=($ analysis of variance $)$ varianciaanalízis; ASMI-skála = (Attitudes to Severe Mental Illness scale) Mentális Betegségek Attitűd-skála (a súlyos mentális betegséggel szembeni attitüdöket mérő skála $) ; \mathrm{BS} c=($ Bachelor of Science $)$ tudományos alapvégzettség; CAMI-skála $=($ Community Attitudes Toward the Mentally Ill scale) Közösségi Hozzáállás a Mentális Betegségekhez-skála (a mentális beteggel szembeni közösségi attitüdöket mérő skála); ELTE = Eötvös Loránd Tudományegyetem; ETT TUKEB = Egészségügyi Tudományos Tanács, Tudományos és Kutatásetikai Bizottság; EU = Európai Unió; KEB = Kutatásetikai Bizottság; MESZK = Magyar Egészségügyi Szakdolgozói Kamara; MSc = (Master of Science) tudományos mesterfokozat; OKJ = Országos Képzési Jegyzék; OMI-skála $=($ Opinion About Mental Illness scale $)$ Vélemény a Mentális Betegségekról-skála

Az orvostudomány többi területéhez képest talán a pszichiátriában a legkevésbé megfoghatók a betegségek és kialakulásuk okai. Ez a megfoghatatlanság lehet az oka, hogy az embereket foglalkoztatja az „elme zavara”, ugyanakkor az irracionalitás sokak számára riasztó, bizonytalanságot, elutasítást keltô [1]. A mentális zavarral küzdő embereknek a saját állapotuk terhein túl a társadalom által rájuk aggatott stigmákkal is meg kell küzdeniük. Egy hazai kutatás eredményei szerint laikus vizsgálati személyekből a pszichiátriai betegség ténye kedvezőtlenebb személyiségmegítélést hív elő, mint ha ugyanarról a személyről nem tudják, hogy beteg; és ez még fokozottabban jelentkezik, ha az adott személy a szkizofrénia diagnózisával rendelkezik [2]. Hasonló eredményre jutott Nieradzik és Cochrane is egy jóval korábbi, 1985-ös vizsgálatban. Igazolták, hogy a pszichiátriai diagnózis nagyobb befolyással van a mentális betegekkel szembeni attitűdre, mint maga az egyén viselkedése, diagnózis nélkül [3]. Az ELTE kutatócsoportja hosszú távú attitűdvizsgálat keretében mérte fel a magyar felnőtt lakosság körében a társadalmi távolság preferenciáit és a mentális betegségekkel kapcsolatos ismereteket. Országos reprezentatív felmérésüket 2001-ben, 2003-ban, 2007-ben és 2015-ben ismételt interjúkkal és önálló kérdőív segítségével végezték el. A trendelemzés során ki- mutatták, hogy 15 év alatt a társadalmi elutasítás tekintetében nem történt jelentőss változás Magyarországon a mentális betegekkel szemben. Megállapították, hogy nagyobb erőfeszítésekre van szükség a mentális zavarok megértése és az elő́téletek, a beteg emberekkel szembeni ellenállás leküzdése érdekében [4]. A társadalom részéről tapasztalható ellenállás annak a hibás képzettársításnak lehet a következménye, amely a mentális betegségeket erôszakos cselekedetekkel, megbotránkoztató viselkedéssel kapcsolja össze. Elsősorban a félelemmel vegyes idegenkedés és az ismeretlen dolgokkal szembeni tehetetlenség érzése sarkallhatja az embereket a mentális problémával élók elutasítására, megbélyegzésére [5]. Hajlamos a közvélemény eltúlozni a pszichiátriai problémával kezelt emberek veszélyességét és a velük kapcsolatban megélt kockázatot. A betegek sok esetben nem elkövetői, hanem elszenvedői az erőszakos cselekményeknek. A szerhasználat során mutatkozik a legtöbb agresszív viselkedés a betegek részérôl [6]. Graham Thornicroft „Shunned” címú könyvében a stigma fogalmát három összetevővel jellemzi: a tudással kapcsolatos problémák (tudatlanság), problémák az attitűddel (előítélet) és a viselkedésben jelentkező problémák (azaz diszkrimináció) [7]. Számos kutatás bizonyította más populációkkal kapcsolatban, hogy az előítéletektől és megbélyegző attitűdtől az egészségügyben dolgozó szakemberek sem mentesek $[8,9]$. Nemzetközi kutatások a mentális betegekkel kapcsolatos elő́téleteket is feltárták. A sztereotípiák, a rejtett negatív attitúdök, az ellátás során tapasztalt megkülönböztetett bánásmód jelentős szerepet játszhat a mentális betegek önbizalmának csökkenésében, a kirekesztettség érzésének tudatosításában, és akadályozzák az elérhetô felépülés folyamatát. Thornicroft és mtsai 2009-ben publikált nemzetközi, multicentrikus kutatásának (INDIGO Study) 732, mentális betegségben szenvedő résztvevője közül 38\% tapasztalt diszkriminációt az egészségügyi szakemberek részéroól [10]. Gyakran számolnak be az egészségügyi személyzet által elkövetett „verbális bántalmazásról” olyan személyek is, akik „önsértés” miatt sürgősségi ellátásra szorulnak [11]. Vizsgálatok erősítik meg, hogy a laikus társadalom tagjaihoz hasonló stigmatizáló attitû́- 
dökkel rendelkeznek az egyéb szakterületek munkatársain túl maguk a mentális betegekkel foglalkozó szakemberek is [12]. Ezek az eredmények figyelemre méltóak, mivel az egészségügyi szakemberek attitűdjei a mentális zavarban szenvedők stigmatizációjának megelőzésében vagy akár megszüntetésében is jelentős szerepet játszhatnak [13]. A betegekkel az ellátás során a szakdolgozók töltik a legtöbb időt, ezért kiemelten fontos, hogy az ápolói attitűd előítéletektől, stigmáktól mentes legyen. A pozitív attitúd, az egyenlő bánásmód, a partneri viszony alapjait és a súlyos állapotú betegeknél alkalmazható hatékony kommunikáció készségszintű elsajátítását az egészségügyi képzések hivatottak biztosítani a szakdolgozók számára. A pszichiátria oktatásához kapcsolódó gyakorlatoknak mind az egészségügyi szakképzés, mind a felsőoktatás területén komoly szerepük van az ápolói attitűd kialakításában. A rögzült sztereotípiák csökkentése, a mentális zavarokkal kapcsolatban a köztudatban lévő félelmek és a betegségeket övező stigmák eloszlatása a korábbi elméleti ismereteket evokáló, valódi esetek feldolgozását és helyzetgyakorlatokat is alkalmazó, edukatív képzés keretében valósulhat meg a leginkább. A fóiskolai hallgatóknak a pszichiátria tantárgyhoz kapcsolódó területi gyakorlatai leginkább a fekvőbetegintézményekre korlátozódnak, a közösségi pszichiátria szellemiségét, a „nem kórházi atmoszférát” nincs lehetőségük megismerni. Egy 2012-es hazai vizsgálat a Semmelweis Egyetem Egészségtudományi Kara BSc Ápolás szakirányú, nappali és levelező tagozatának végzős hallgatói körében mérte fel a hallgatók viszonyulását a mentális betegekhez, a pszichiátria tantárgy gyakorlatainak megkezdése előtt és a területi gyakorlatok után. A területi gyakorlat előtt a felmérésben részt vevő hallgatók 44\%-a tartotta a mentális betegségben szenvedő embereket agresszívnek, míg a kórházi gyakorlat után ez 49\%ra változott. A megkérdezettek 58\%-a érezte úgy az oktatás megkezdése előtt, hogy nem szívesen dolgozna pszichiátrián, és jelentős változást a gyakorlat sem hozott [14]. Nem kérdés az elméleti ismeretek mellett a gyakorlatok relevanciája a hallgatók mentális zavarokkal szembeni látásmódjának alakulásában. A gyakorlati helyszíneken uralkodó szemlélet és az ott dolgozók attitúdje mintául szolgálhat a hallgatóknak a betegekkel való bánásmód terén. Az oktatást végző szakembernek a betegeihez való saját viszonyulása, kommunikációja és a „holisztikus emberkép” megjelenése az ápolási munkában meghatározó jelentőségű [15]. A témában végzett hazai vizsgálatok száma relatíve kicsi. Magyarországon tudomásunk szerint korábban nem készült egészségügyi szakdolgozók körében felmérés a mentális betegségekkel kapcsolatos ismeretekről, a betegségben érintettekhez való viszonyulásról és a stigmatizáló attitűd jelenlétéről. Az alábbiakban bemutatásra kerülő vizsgálatunk eredményei alátámasztják a téma aktualitását, és egyben reprezentálják a téma kutatásának nehézségeit is.

\section{Célkitüzések}

Egy olyan, egészségügyi szakdolgozók körében végzett attitűdvizsgálat lefolytatását tűztük ki általános célul, amelynek eredményeit felhasználva a mentális zavarban szenvedő emberek elfogadását és az ápolói hivatás értékeit növelő javaslatokat tehetünk az ápolóképzések reformjára vonatkozóan. Ehhez a magyarországi egészségügyi intézményekben, adott szakterületeken dolgozó ápolók bevonásával, online kérdőíves vizsgálat lefolytatását kezdeményeztük, amelynek konkrét célkitűzése volt a rejtett stigmatizáló attitüdök jelenlétének, valamint a mentális betegségekkel kapcsolatos ismereteknek a felmérése, egy korábban már validált antistigmaskála és saját kérdésekből összeállított kérdőív felhasználásával.

\section{Módszer}

\section{Mintavételi eljárás}

Kérelemben részletezett kutatási tervünket a KEB megvizsgálta, és a szakmai-etikai engedélyt az ETT TUKEB 47854-2/2018/EKU számon megadta. A vizsgálat kvantitatív elemzését megalapozó elektronikus kérdőívet a Google kifejezetten online kérdőívek programozására szolgáló alkalmazásában fejlesztettük. A MESZK segítségével juttattuk el a vizsgált populáció - a megcélzott ápolói szakterületeken dolgozók - részére úgy, hogy a Kamara megjelentette a honlapján, illetve rendszeresen összeállított hírlevelében elküldte a feliratkozottak személyes e-mail-címére. Alapsokaságnak a MESZK felnőttápolási tagozatának ( $\mathrm{n}=28$ 030), pszichiátriai ápolási tagozatának $(\mathrm{n}=983)$, valamint mentésügyi és sürgősségi ellátási tagozatának ( $\mathrm{n}=4878$, a hasonló profil miatt összevonva) személyes hírlevélre regisztrált ápolóit tekintettük. A Facebook „Tankórterem” nevű oldalán szintén megosztásra került a kérdőív. Egyéni megkeresés nyomán hazai, vezető beosztású ápolási szakemberek is segítettek a kérdőív minél szélesebb körben való terjesztésében. Az adatfelvétel 2019. január 31én kezdődött és 2019. április 30-án zárult, s ebben az időszakban 515 kitöltés érkezett az online felületre. Az adatfájl technikai tisztítása során 495 kitöltés bizonyult elemzésre alkalmasnak.

\section{Mérôeszköz}

A szociodemográfiai adatok elemzésekor vizsgáltuk a kitöltők nemét, legmagasabb szakmai végzettségét, a munkavégzés helyét (megyei bontásban), az egészségügyi pályán eltöltött éveik számát, valamint azt, hogy melyik egészségügyi szakterületen dolgoznak. Szociológus szakértői javaslatra 5 kategóriás változóként vizsgáltuk, hogy a kitöltő találkozott-e már életében mentális beteggel. A „családban”, „baráti társaságban”, a „szomszédságban”, „a munkám során”, illetve a „nem találkoztam még” kategóriák közül választhattak a kitöltők. Egy 
következő, saját szerkesztésű kérdésben 21, mentális egészséggel kapcsolatba hozható fogalom/kórkép besorolását kértük a válaszadóktól a „rossz szokás”, „viselkedészavar”, „ideggyógyászati betegség” és „mentális betegség” kategóriákba. Ezt követte az a kérdés, amely az általuk 3 legsúlyosabbnak ítélt betegség kiválasztására irányult. Egy újabb kérdésben tüneteket soroltunk fel, és az ápolási munka során számukra a legtöbb nehézséget okozó 3 tünet kiválasztását kértük. Ugyanezt megismételtük diagnózisok felsorolásával, a megítélésük szerint ápolási szempontból legnehezebb 3 kórkép kiválasztását kérve. Az addiktológiai betegekkel és a szkizofréniában szenvedőkkel kapcsolatos érzéseket, a differenciálás mögött meghúzódó rejtett attitűdöket szerettük volna feltárni a betegek egyéni felelősségére irányuló, választásos kérdéssel. 5 fokozatú Likert-skálán (1-es érték „egyáltalán nem értek egyet”, 3-as érték „közömbös számomra”, 5-ös érték „teljes mértékben egyetértek”) az egészségügyi képzés hatékonyságára, a saját ismereteik és empátiájuk összefüggéseire vonatkozó alábbi két állítással való egyetértést mértük: „Úgy érzem, a korábbi tanulmányaim során nem sajátitottam el megfeleló elméleti és gyakorlati ismereteket a pszichiátriai betegekkel való bánásmód és kommunikáció terén.” „Ha jobban érteném a pszichiátriai betegségeket, nagyobb együttérzéssel ápolnám az ilyen problémával küzdō embereket.” A szeparációs attitüd jelenlétét vizsgáltuk ugyancsak az 5 fokozatú egyetértési skála alkalmazásával a következő két állítással: „A pszichiátriai betegeket nem kellene ugyanabban a kórházban gyógyitani, mint a testi betegségben szenvedőket.” „Magyarország is megkezdte a nagy létszámú, többnyire kastélyokban kialakitott szociális otthonok féröbelyeinek kiváltását. Helyesnek tartom, hogy a pszichiátriai betegeket a közösségbe, kisebb, önálló házakba költöztessék ki.” A kérdőív saját szerkesztésű kérdéseit a pszichiátriai betegekről eszükbe jutó 3 jelző, továbbá a kutatáshoz kapcsolódó bármilyen észrevétel, hozzáfüznivaló nyitott kérdése zárta, az ASMI-skála után beillesztve. A kvantitatív vizsgálat hátrányainak ellensúlyozására a kérdőív végén elkértük azoknak az elérhetőségét, akik szívesen beszélgetnének még a pszichiátriai betegségekkel kapcsolatos attitűdökről, megteremtve ezzel a vizsgálat későbbi, fókuszcsoportos vagy egyéni interjúkat alkalmazó folytatásának lehetőségét.

\section{Az ASMI (Attitudes of Severe Mental Illness)- skála}

A kérdőív összeállításakor arra törekedtünk, hogy olyan mérőskálát használjunk, amely más mintában tesztelve már bizonyította, hogy alkalmas eszköz a rejtett attitüdök mérésére. Fontos kritérium volt, hogy a skála kérdései összhangban legyenek a kutatási kérdéseinkkel. A skála terjedelmére vonatkozó elvárásunk az volt, hogy olyan itemszámú mérôeszközt találjunk, amely a saját szerkesztésü kérdésekkel kiegészítve sem haladja meg az 50 itemet. Több mérőeszköz tanulmányozása után az ASMI- skála alkalmazására esett a választásunk. Az ASMI-skálát korábbi skálák felhasználásával 2012-ben fejlesztették ki Madianos és szerzôtársai [16]. Az 1960-as évek elején Cohen és Struening alkotta meg a széles körben használt, 51 itemből álló OMI (Opinion About Mental Illness)skálát két nagy pszichiátriai intézmény 1194, mentális egészségügyi szakembere válaszának összesítése alapján [17]. Az OMI-skála módosított verziójaként Taylor és Dear kifejezetten a közösségi ideológiák vizsgálatára fejlesztette ki az 1970-es évek végén a CAMI (Community Attitudes Toward the Mentally Ill)-skálát [18]. Görögországban az 1980-90-es években az OMI-skálát szabványosították és használták a mentális betegségekkel szembeni attitűd mérésére, az általános népesség és az egészségtudományi képzéseken tanuló hallgatók vizsgálatához [16]. A mentális betegségek megbélyegzésével foglalkozó irodalom alapos áttekintése után született döntés egy olyan eszköz kifejlesztéséről, amely alkalmas a kortárs gondolkodás megragadására, valamint a görög társadalomban a félelem és pusztítás fogalmával összekapcsolódó „szkizofrénia” fogalom helyett a „súlyos mentális betegség” kifejezést használja. Az új skála, az ASMI kifejlesztését a korábbi skálák (OMI, CAMI) felhasználásával laikusokból, mentális betegekből és hozzátartozókból álló fókuszcsoportok segítségével végezték el. Főkomponens-analízis során azonosították a „sztereotipizálás”, „optimizmus”, „megküzdés” és „empátia” faktorokat. A validálási procedúrát követően, edukált telemarketinges szakembereket alkalmazva, telefonos interjút készítettek a 2039 felnőttből álló, országos reprezentatív mintával [16]. Saját kutatásunkban a görög kutatók validálási eredményeire hagyatkoztunk. A vizsgálatot megelőzte az angol nyelvű skála magyarra fordítása, ennek angol nyelvre való visszafordítása és a kettő egybevetése, független fordítók segítségével. Vizsgálatunkat az ASMI-skála magyar nyelvű fordítása, a Mentális Betegségek Attitűd Skála felhasználásával végeztük el.

\section{Adatfeldolgozás és -elemzés}

Az adatok feldolgozását és elemzését az SPSS 23.0 statisztikai programcsomag (IBM Corporation, Armonk, NY, Amerikai Egyesült Államok) segítségével végeztük. Az elemzés során az egyes kérdésekre adott válaszok relatív gyakorisági eloszlását, a képzett indexek esetében emellett azok leíró statisztikáit vizsgáltuk. Az antistigmaindex és részindexei az egyes vonatkozó itemek számtani átlagaként adódtak. A hipotézisek vizsgálatakor elsősorban kontingenciatáblák (kereszttáblák) elemzését és $\chi^{2}$ alapú függetlenségvizsgálatot (independence test) végeztünk. Azon hipotézisek esetében, amelyek a képzett indexekre vonatkoztak, a több várható érték egyezőségének hipotézisét egyutas varianciaanalízissel (one-way ANOVA) teszteltük. 
1. táblázat A szociodemográfiai mutatók alakulása $(\mathrm{n}=495)$

\begin{tabular}{ll}
\hline Nemek & Férfi $-50 \quad$ Nő -445 \\
\hline Iskolai végzettség: & egészségügyi szakiskola \\
& (érettségi nélkül) -13 \\
& szakközépiskola \\
& (érettségivel) -38 \\
& OKJ -239 \\
& fóiskola/BSc -154 \\
& egyetem -51 \\
\hline A munkavégzés helye: & Budapest -170 \\
& Pest megye -40 \\
& egyéb megye -285 \\
\hline Mióta dolgozik ápolóként: & $>15$ év -336 \\
& $5-15$ év -90 \\
& pályakezdő -69 \\
\hline Szakterület: & pszichiátria -129 \\
& mentős/sürgősségi -71 \\
& egyéb (felnőttápolás) - 295 \\
\hline
\end{tabular}

BSc = tudományos alapvégzettség; OKJ = Országos Képzési Jegyzék

\section{Eredmények}

A demográfiai mutatók alakulását az 1. táblázatban mutatjuk be. (A felnőttápolási tagozat tagjai számos szakterületet képviselnek, őket „egyéb” kategóriaként jelenítjük meg a táblázatban és a 3. ábrán.) A mentális beteggel való találkozásra irányuló kérdésnél az derült ki, hogy élete során csupán 2 válaszadó nem találkozott még pszichiátriai beteggel, ők mindketten a felnőttápolási szakmacsoporthoz tartoznak. Az ápolók nagy többsége a munkája során minden szakterületen találkozott már mentális beteggel, de a felnőttápolásban dolgozók 36\%ának a családjában, a mentés és a sürgősségi ellátás területén dolgozók 25\%-ának pedig a baráti körében is van mentális problémával élő személy. A megadott kórképek azonosításával foglalkozó kérdésre érkezett válaszok esetében kiemelendő, hogy a válaszadók jelentős hányada értékeli a különböző függőségeket rossz szokásként. Különösképpen a nikotinfüggőséggel megengedők, 60,2\% csak rossz szokásnak tartja. Jól látszik ezenkívül például az autizmussal kapcsolatos diagnosztikus bizonytalanság. A delirium tremenst is közel $40 \%$ pszichiátriai, illetve hasonló számú kitöltő neurológiai betegségnek tartja, de a viselkedészavar és a rossz szokás kategóriájába is többen sorolták (2. táblázat).

A 2. táblázatban felsorolt kórképek közül magasan a szkizofrénia került ki elsőként, 42\%-os említési gyakorisággal. A második helyre a dementia (24\%), a harmadikra pedig a pedofília (23\%) került (1. ábra).

A tünetekre vonatkozó kérdésben a kérdőívet kitöltők közel 80\%-a a fizikai agressziót, 64\%-a az elutasító magatartást és az együttműködés hiányát, $54 \%$-a pedig a verbális agressziót jelölte meg mint az ápolási munkát a leginkább megnehezítő tényezőt (2. ábra).

A három legnehezebben ápolható diagnózisként a drogfüggőséget (59\%), az alkoholizmust/részegséget
2. táblázat $\mid$ Kórképek kategóriákba sorolása (soronként egy válasz volt le hetséges; $\mathrm{n}=495$ )

\begin{tabular}{|c|c|c|c|c|}
\hline & $\begin{array}{l}\text { Rossz } \\
\text { szokás }\end{array}$ & $\begin{array}{l}\text { Viselke- } \\
\text { dészavar }\end{array}$ & $\begin{array}{l}\text { Mentális } \\
\text { betegség }\end{array}$ & $\begin{array}{c}\text { Ideg- } \\
\text { gyógyászati } \\
\text { betegség }\end{array}$ \\
\hline Dementia & $0,4 \%$ & $8,1 \%$ & $54,8 \%$ & $36,7 \%$ \\
\hline Nikotinfüggőség & $60,2 \%$ & $10,2 \%$ & $28,3 \%$ & $1,3 \%$ \\
\hline Delirium tremens & $4,8 \%$ & $14,0 \%$ & $39,5 \%$ & $41,8 \%$ \\
\hline Depresszió & $0,2 \%$ & $10,4 \%$ & $79,9 \%$ & $9,5 \%$ \\
\hline Sclerosis multiplex & $0,4 \%$ & $4,7 \%$ & $2,3 \%$ & $92,6 \%$ \\
\hline Heroinfüggőség & $26,1 \%$ & $13,5 \%$ & $56,3 \%$ & $4,1 \%$ \\
\hline Szadizmus & $5,2 \%$ & $47,3 \%$ & $43,6 \%$ & $3,9 \%$ \\
\hline Anorexia/bulimia & $5,0 \%$ & $22,1 \%$ & $68,1 \%$ & $4,8 \%$ \\
\hline Internetfüggőség & $44,5 \%$ & $21,0 \%$ & $33,7 \%$ & $0,8 \%$ \\
\hline Epilepszia & $0,0 \%$ & $5,5 \%$ & $1,7 \%$ & $92,9 \%$ \\
\hline Szkizofrénia & $0,0 \%$ & $9,9 \%$ & $67,8 \%$ & $22,4 \%$ \\
\hline Alkoholizmus & $27,4 \%$ & $14,0 \%$ & $56,1 \%$ & $2,5 \%$ \\
\hline Pedofília & $4,3 \%$ & $36,0 \%$ & $56,3 \%$ & $3,3 \%$ \\
\hline Hisztéria & $10,6 \%$ & $50,4 \%$ & $33,4 \%$ & $5,6 \%$ \\
\hline Kényszeres vásárlás & $22,6 \%$ & $34,4 \%$ & $41,9 \%$ & $1,0 \%$ \\
\hline Narcolepsia & $1,5 \%$ & $7,1 \%$ & $19,3 \%$ & $72,1 \%$ \\
\hline Mentális retardáció & $1,0 \%$ & $7,5 \%$ & $62,2 \%$ & $29,3 \%$ \\
\hline Fóbia & $5,9 \%$ & $23,6 \%$ & $64,4 \%$ & $6,1 \%$ \\
\hline Autizmus & $0,6 \%$ & $13,8 \%$ & $43,2 \%$ & $42,3 \%$ \\
\hline Parkinson-kór & $0,6 \%$ & $5,3 \%$ & $4,2 \%$ & $89,9 \%$ \\
\hline Paranoia & $2,7 \%$ & $13,2 \%$ & $74,0 \%$ & $10,1 \%$ \\
\hline
\end{tabular}

(51\%), valamint az antiszociális személyiségzavart (45\%) jelölték meg. A kitöltők 13\%-a gondolja úgy, hogy sem a drog- és alkoholbetegek, sem a szkizofréniával diagnosztizáltak nem felelősek a betegségükért, 7\% szerint viszont mindkét csoportot felelősség terheli. A döntő többség, $81 \%$ szerint az addiktológiai problémákért van a betegnek személyes felelössége, míg a szkizofrénia kialakulásáért nincs. A mentős-sürgôsségi ápolók körében magasabb azok aránya, akik mindkét csoportot felelőssé teszik, míg a pszichiátriai ápolók között elterjedtebb az a vélemény, hogy egyik csoport sem felelős az állapotáért $(\mathrm{p}=0,005)$. A saját fejlesztésű kérdések között vizsgáltuk a korábbi egészségügyi képzések hatékonyságának szubjektív megítélését. A válaszadók 47\%-a inkább egyetért azzal az állítással, hogy korábbi tanulmányai során nem sajátított el megfeleló elméleti és gyakorlati ismereteket a pszichiátriai betegekkel való bánásmód és kommunikáció terén $(\mathrm{p}=$ 0,000 ). A pszichiátriai ápolók körében is viszonylag nagy arányú, 27\% azok aránya, akik hiányosnak ítélik meg saját felkészültségüket, ugyanakkor természetesen a megfelelő felkészültséget is ez a csoport választotta a legnagyobb arányban. A mentési és sürgősségi ápolói csoport válaszadóinak majdnem fele $(49 \%)$ ítéli meg a saját korábbi képzésének hatékonyságát negatívan, ezzel ők a leginkább kritikusak a saját oktatásukat illetően. Az oktatás 


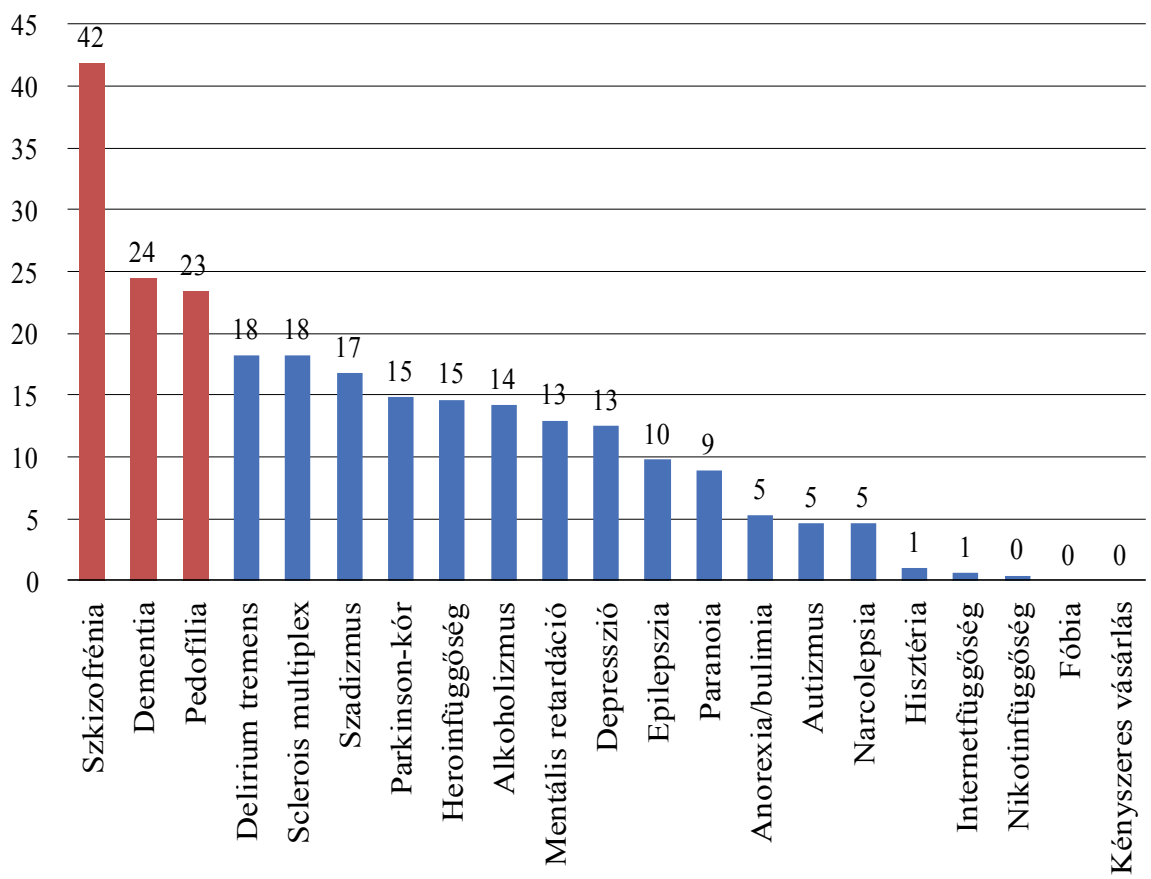

1. ábra | A kórképek súlyosságának megítélése (az említések gyakorisága százalékban; n = 495)

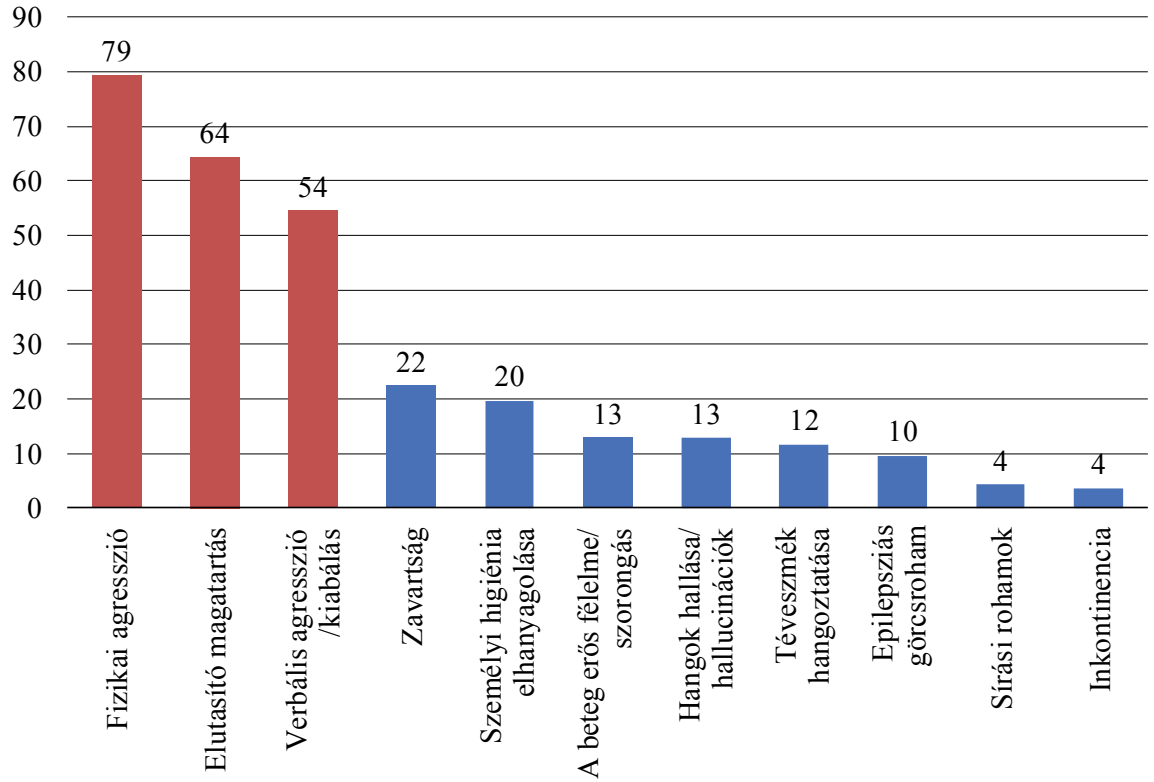

2. ábra | Az ápolási munka szempontjából nehézséget jelentó tünetek (az említések gyakorisága százalékban; n = 495)

során szerzett ismeretek és az empátia közötti összefüggést vizsgáló kérdésünk esetében a válaszadók több mint fele (55\%) inkább egyetért azzal, hogy ha jobban értené a pszichiátriai betegségeket, nagyobb együttérzéssel ápolná az ilyen problémával küzdő embereket. Ebben a kérdésben a különböző szakterületek ápolói között nincs szignifikáns eltérés (3. ábra).

A kirekeszto" attitüdre irányuló kérdésnél a válaszadók 40\%-a szerint nem kellene, másik $40 \%$ szerint viszont lehetne ugyanabban a kórházban gyógyítani a pszichiátriai betegeket, mint a testi betegségben szenvedőket. Mar- káns különbség van a pszichiátriai ápolók esetében a többi szakterülethez képest a kérdés megítélésében: körükben 60\% támogatja a „vegyes” kórházak kialakítását. A teljes minta közel 60\%-a helyesnek tartja, hogy a pszichiátriai betegeket a közösségbe, kisebb, önálló házakba költöztessék ki, míg mintegy 20\% nem ért ezzel egyet. A mentôs-sürgősségi ápolók körében nagyobb az elutasítás aránya $(\mathrm{p}=0,006)$.

A Mentális Betegségek Attitűd Skála (3. táblázat) 30 attitűdkérdésére adott válaszok megoszlását az összes válaszadóra és szakterület szerinti bontásban elemeztük. 


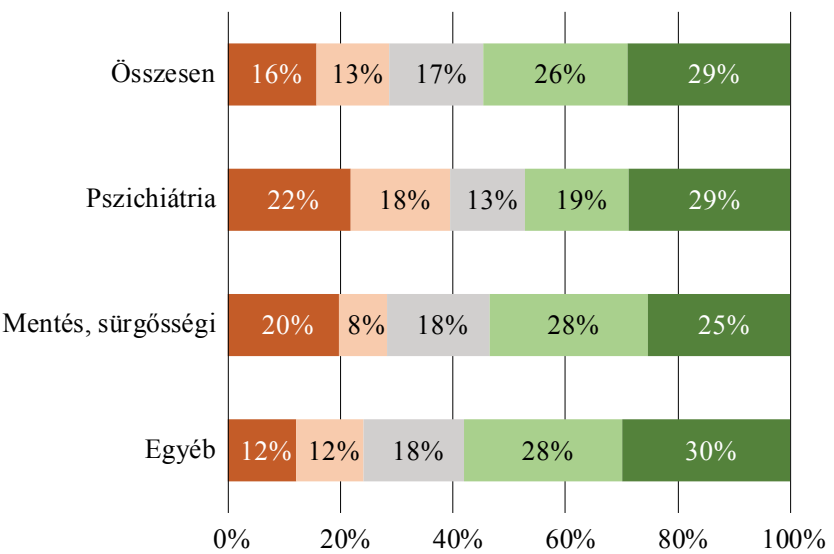

Egyáltalán nem ért egyet $\quad 2 \quad 3 \quad 4 \quad$ पeljes mértékben egyetért

3.ábra $\quad$ A mentális betegségek ismerete és az empátia összefüggései (százalék; $\mathrm{n}=491 ; \mathrm{p}=0,060)$
A $\chi^{2}$-alapú függetlenségvizsgálat eredménye az adott kérdéssel való egyetértés fokát és a szakterület közötti kapcsolat meglétét vizsgálta. Amennyiben a p-érték kisebb vagy egyenlő 0,05 -tel, akkor $5 \%$-os szignifikanciaszinten van kapcsolat a két változó között. A 30 itemes skála antistigma-alindexeinek végső értékeihez vezető részeredményeiből néhány figyelemre méltó adatot szeretnénk kiemelni. A válaszadók fele (53\%) inkább egyetért azzal az állítással, hogy a súlyos mentális betegség miatt az ember élete végéig szenvedni fog. A mentésügyi és sürgősségi ellátók körében nagyobb az egyetértés az állítással, mint a többi szakterületen dolgozók körében. A pszichiátrián dolgozóknak is közel fele $(47 \%)$ egyetért az állítással $(\mathrm{n}=492 ; \mathrm{p}=0,001)$. A válaszadók $37 \%$-a inkább egyetért azzal az állítással, hogy a súlyos mentális betegségben szenvedő emberek nem olyanok, mint más

3. táblázat | Mentális Betegségek Attitűd Skála (az ASMI-skála magyar verziója)

1. Ha valaki súlyos mentális betegségben szenvedett valaha, élete végéig szenvedni fog tóle.

2. A súlyos mentális betegségben szenvedő emberek mind csődtömegek.

3. Minden erőfeszítés ellenére, a súlyos mentális betegségben szenvedő emberek sosem lesznek olyanok, mint a többi ember.

4. A súlyos mentális betegségben szenvedő embereknek életük végéig gyógyszert kell szedniük.

5. Meglátszik egy emberen, ha súlyos mentális betegsége van.

6. A súlyos mentális betegségben szenvedő emberek nem olyanok, mint más emberek.

7. A súlyos mentális betegségek könnyen felismerhetôk.

8. A súlyos mentális betegségben szenvedő emberek képtelenek új készségek elsajátítására.

9. A súlyos mentális betegségben szenvedő emberek veszélyesek.

10. A súlyos mentális betegség balszerencse.

11. A pszichiátriai gyógyszerek függőséget okoznak.

12. Egy súlyos mentális betegségben szenvedő személy képes dolgozni.

13. Egy súlyos mentális betegségben szenvedő személyt ki lehet képezni egy munkára.

14. A súlyos mentális betegségben szenvedő emberek nem különböznek más emberektől.

15. A súlyos mentális betegségben szenvedő emberek képesek megküzdeni az életben felmerülő nehézségekkel.

16. Attól, hogy valaki pszichiátriai gyógyszert szed, még nem lesz más, mint a többi ember.

17. A súlyos mentális betegségben szenvedő emberek manapság már fel tudnak épülni.

18. A súlyos mentális betegségben szenvedő embereknek nem szabad feladniuk.

19. A súlyos mentális betegségben szenvedő embereknek specialista segítségét kell kérniük.

20. Ha valaki súlyos mentális betegségben szenved, jobb, ha olyan emberekkel barátkozik, akiknek ugyanilyen problémájuk van.

21. Jobb a problémákat eltitkolni, hogy elkerüljük a nehézségeket.

22. A súlyos mentális betegségben szenvedő embereket a barátaiknak nem kellene magukra hagyniuk.

23. Jobb, ha egy súlyos mentális betegségben szenvedő ember elkerüli a többi embert.

24. Ha valaki súlyos mentális betegségben szenved, azt nem szabad eltitkolnia a családja és a barátai elôttt.

25. A súlyos mentális betegségben szenvedő emberek úgy érzik, terhet jelentenek a családjuk számára.

26. A súlyos mentális betegségben szenvedő emberek általában alsóbbrendúnek érzik magukat.

27. A súlyos mentális betegségben szenvedő emberekkel általában másképpen bánnak a többiek.

28. A súlyos mentális betegségben szenvedő embereket hibáztatják a család szenvedéséért.

29. A súlyos mentális betegségben szenvedő emberek általában felelősnek érzik magukat a problémáikért.

30. A súlyos mentális betegségben szenvedő embereket nehezen érti meg a többi ember.

ASMI-skála $=$ a súlyos mentális betegséggel szembeni attitűdöket mérő skála 
emberek. Közel ugyanennyien, 4l\% nem értett egyet az állítással. A legnagyobb fokú egyetértés a mentésügyi és sürgősségi ellátók körében látható, ahol a válaszadók fele szerint a mentális betegek különböznek a többi embertöl (harmaduk ráadásul teljes mértékben egyetértett.) Ezzel szemben a pszichiátrián dolgozók $60 \%$-a szerint nincs különbség a mentális betegek és a többi ember között $(\mathrm{n}=494 ; \mathrm{p}=0,000)$. Szakterületi bontásban érdemi különbségek láthatók a mentális betegek veszélyességének megítélésében. A pszichiátrián dolgozók kétharmada, míg a mentésügyi és sürgősségi ellátóknak csak mindöszsze egyharmada (31\%) gondolja úgy, hogy nem veszélyesek. A többi szakterület dolgozói az átlagnak megfelelő arányban, közel 50\%-ban nem értenek egyet az állítással $(\mathrm{n}=492 ; \mathrm{p}=0,000)$. A válaszadók döntő többsége szakterülettől függetlenül egyetért azzal, hogy a többi embernek nehéz megérteni a súlyos mentális betegségben szenvedőket. Mindössze a válaszadók 5\%-a gondolja úgy, hogy ez nem így van $(\mathrm{n}=493 ; \mathrm{p}=0,290)$. Szakterülettől függetlenül a válaszadók többsége egyetértett azzal, hogy a súlyos mentális betegségben szenvedő emberekkel általában másképpen bánnak a többiek. Az egyet nem értők aránya 4-6\% között alakult $(\mathrm{n}=494 ; \mathrm{p}=0,139)$.

\section{Az antistigmaindex és alindexeinek bemutatása}

A kérdőívben szerepeltetett attitűdállítások Madianos és szerzôtársai szerint alkalmasak az antistigmatizáló attitüd megragadására. Az állításokból faktoranalízis alkalmazásával négy latens attitűdöt azonosítottak: 1) a sztereotipizálást, 2) az optimizmust, 3) a megküzdést és 4) az empátiát. A megbízhatóság (reliability) és az érvényesség (validity) vizsgálata után végső konklúziójuk szerint a közzétett attitűdállítások alkalmasak az antistigmatizációs attitűd megragadására. Elemzésünkben erre támaszkodva az egyes állításokra adott válaszokat tematikusan átlagoltuk, hogy megkapjuk a négy attitüd szerinti alindexeket, majd ezek - szintén súlyozatlan, számtani - átlagaként az antistigmaindexet minden olyan válaszadó esetében, aki az összes állításra érvényes választ adott.

A leíró statisztikák alapján (4. táblázat) a sztereotipizálás, az optimizmus és az empátia vonatkozásában is megjelentek egészen szélsőséges véleménnyel rendelkező válaszadók. A legkisebb terjedelem a megküzdés alindex esetében figyelhetó meg. Ebben a dimenzióban látható a legmagasabb fokú egyetértés az antistigmatizáló állí-

4. táblázat |Az antistigmaindex és az alindexek leíró statisztikái

\begin{tabular}{l|ccccc}
\cline { 2 - 6 } & $\begin{array}{c}\text { Elem- } \\
\text { szám }\end{array}$ & $\begin{array}{c}\text { Mini- } \\
\text { mum }\end{array}$ & $\begin{array}{c}\text { Maxi- } \\
\text { mum }\end{array}$ & Átlag & Szórás \\
\hline Antistigmatizációs index & 462 & 2,3 & 4,7 & 3,6 & 0,4 \\
\hline Sztereotipizálás alindex & 478 & 1,0 & 4,9 & 2,8 & 0,7 \\
Optimizmus alindex & 491 & 1,2 & 5,0 & 3,2 & 0,8 \\
Megküzdés alindex & 486 & 2,3 & 5,0 & 4,4 & 0,5 \\
Empátia alindex & 489 & 1,2 & 5,0 & 3,7 & 0,6 \\
\hline
\end{tabular}

tásokkal, és itt figyelhető meg a legkisebb szórás is a válaszadók között, ami nagyfokú homogenitást jelez a megkérdezettek véleményében. A legnagyobb véleménykülönbségek az optimizmus tekintetében figyelhetők meg. Ezt támasztja alá az egyes indexek gyakorisági eloszlása is. A sztereotipizálás és az optimizmus alindexek esetében látható széttartás a válaszadók véleményei között, míg az empátia, de különösen a megküzdés viszonylatában egyöntetü a pozitív attitüd. Az antistigmaindex a négy alindex számtani átlagaként került meghatározásra. Ennek alapján a válaszadók között nem szerepelnek szélsőségesen stigmatizáló attitüddel rendelkező személyek. Ez a megfigyelés akár a módszertan kritikáját is jelenthetné, mivel a megfigyelési egységek nem töltik ki a mutató teljes értelmezési tartományát. Érdemes ugyanakkor figyelembe venni, hogy a Madianos és szerzôtársai által kifejlesztett skála a teljes népesség stigmatizáló attitűdjeit hivatott felmérni. Így nem meglepő, hogy az ápolók között, akik szakmájuk gyakorlása közben találkoznak mentálisan súlyosan sérült betegekkel, kevésbé gyakori a szélsőségesen stigmatizáló attitúd. Varianciaanalízissel összehasonlítottuk az antistigmaindex átlagértékeit a különböző szociodemográfiai ismérvek mentén képzett csoportokban. Ez alapján 5\%-os szignifikanciaszinten igazolást nyert az, hogy a szakterület szerint különböznek egymástól az antistigmaindex átlagai. A pszichiátriai ápolók esetében figyelhető meg a legmagasabb $(3,72)$ átlag, ezt követi a felnőttápolási tagozat „egyéb” ápolóinak átlaga $(3,64)$, és a legalacsonyabb antistigmaértéket a mentős-sürgősségi területen dolgozók érték el átlagosan $(3,56)$. A szakmai tapasztalat hossza szerint szintén szignifikáns eltéréseket tapasztalunk, ugyanakkor a kapcsolat a területen eltöltött évek száma és az antistigmaattitüd között nem monoton, nem mondható el, hogy minél több ideje dolgozik az ápoló, annál inkább jellemző rá a stigmatizáló attitüd. A varianciaanalízis igazolta, hogy a föiskolai vagy egyetemi (felsöfokú) iskolai végzettséggel rendelkezők kevésbé stigmatizálók. Figyelembe véve, hogy található szignifikáns különbség az antistigmaindex átlagos értékeiben bizonyos ismérvek mentén, felmerülhet a kérdés, hogy az indexet alkotó négy alindex közül melyek felelősek ezért a különbségért. Ennek vizsgálatára további ANOVA-teszteket végeztünk a szociodemográfiai változók mentén az alindexek átlagaira. A sztereotipizálás alindex (továbbra is az alacsonyabb érték jelöli a kevésbé stigmatizáló attitűdöt) esetében szignifikáns és markáns különbség figyelhetô meg a pszichiátriai ápolók javára, különösen a mentős-sürgősségi ápolókkal szemben. Ebból a szempontból a szakmai tapasztalat mentén nem láthatók szignifikáns különbségek, viszont a felsőfokú végzettségüekre és a budapestiekre kisebb fokú sztereotipizálás jellemzó. Az optimizmus alindex esetében is a pszichiátria felől érkezik a pozitívabb hozzáállás, és a mentôs-sürgösségire jellemzô" a legkevésbé az optimizmus; valamint a felsőfokú végzettségúek átlagosan nagyobb pontszámot értek el, mint a szakképesítéssel rendelkezők és az OKJ-képzést végzettek. 
Összességében az eredmények azt mutatják, hogy a pszichiátriai ápolókra kevésbé jellemzó a stigmatizáló attitüd, mint az egyéb területeken dolgozókra, különösen a mentốs-sürgösségi területen ápolókra. Ez a különbség döntően a sztereotipizálás kisebb és az optimizmus nagyobb átlagos fokára vezethető vissza. A szakmai tapasztalatban adódnak eltérések, a kapcsolat azonban nem monoton, kizárólag a megküzdés tekintetében látható a rövid, legfeljebb egy éve dolgozók esetében kiemelkedő pozitív attitűd. A felsôfokú iskolai végzettségüekre kevésbé jellemzo" a stigmatizáló attitüd, de ehhez hasonló különbség nem figyelhető meg fóváros-vidék viszonylatban: csak a sztereotipizálás hiányának tekintetében tud előnyt felmutatni Budapest.

\section{Megbeszélés}

Vizsgálatunkban az ápolók mentális betegségekkel kapcsolatos ismereteit és a betegségben érintett emberekkel szembeni attitűdjét helyeztük a középpontba. Az elektronikus, önkitöltéses kérdőív módszerét választottuk, melynek előnye a rendkívüli költség- és időigényes személyes vagy telefonos kérdezéssel, illetve a postaival szemben az, hogy viszonylag rövid idő alatt, az anonimitást megnyugtató módon biztosítva, nagy mennyiségú adatot lehetséges begyújteni és feldolgozni vele, minimális anyagi ráfordítással. Ugyanakkor a visszaérkezési arány nem befolyásolható, ami a vizsgálatok reprezentativitásának rizikótényezője. Saját vizsgálatunkban vállaltuk ezt a kockázatot, az alapsokaság nagy számára való tekintettel, akik a MESZK személyes hírlevélre regisztrált szakdolgozói közül kerültek ki. Tettük ezt annak ellenére, hogy ismert számunkra több kutatás problémája, az alacsony kitöltési hajlandóság. A MESZK elektronikus felületén keresztül korábban számos, országos kiterjesztésű felmérés készült. Ezek közül csupán az egészségügyi szakdolgozók munka- és védőruhájának kérdésében készült országos vizsgálat érte el a 10\%-os reprezentációt, valamint egy homogén vizsgálati csoportban, a védőnők körében készült, a szakmai és anyagi helyzetükkel kapcsolatos felmérés, amely meghaladta a 30\%-ot. Más szakmaterületen elektronikus úton készült, szúk érdeklődésre számot tartó kutatás csupán 3-8\% közötti részvételi aránnyal került feldolgozásra. A jelen vizsgálat is e kategóriába sorolható. A legtöbb szakdolgozót a tûszúrásos balesetek vizsgálatának tárgyában sikerült eddig bevonni, de e korábbi vizsgálatok 2006 és 2013 között papíralapú önkitöltős kérdőívek felhasználásával készültek. Kutatásunk limitáló tényezőjének tekintjük tehát, hogy a kérdőív széles körü, több platformon történő terjesztése ellenére a részvételi arány elmaradt az előzetes várakozásoktól. Összességében a laikusok szürésére kifejlesztett ASMIskála, a pluszkérdésekkel kiegészítve, alkalmasnak bizonyult a negatív vélemények feltárására. A minta vizsgálati eredményei igazolták az egészségügyi szakdolgozók körében a rejtett negatív attitűdök, sztereotípiák jelenlétét, ugyanakkor fontos kérdésekre is rávilágítottak. Figye- lemre méltó, hogy a vizsgálatban részt vevő ápolók nagy része úgy érzi, nem kapott elegendő „muníciót” a képzésein a mentális betegségek megértéséhez, a betegekkel való megfelelő bánásmódhoz vagy az akut állapotú betegekkel való kommunikációhoz. A szakképzésben a neurológia és a pszichiátria elméleti oktatása nem volt mindig elkülönítve egymástól. Jelenleg is használatban van olyan, a pszichiátriát kisklinikumként tárgyaló tankönyv, mely „Ideggyógyászati szakápolástan” gyưjtőfejezetében öt és fél oldalt szentel a pszichiátriai betegségeknek [19]. $\mathrm{Az}$ agresszív beteggel való hatékony kommunikációt, illetve az asszertív technikákat az OKJ-képzések gyakran egy napba tömörített kommunikációs moduljában kell a hallgatóknak elsajátítaniuk. Irinyi és mtsai az egészségügyi dolgozókat ért agressziót vizsgáló kutatásukban megállapították, hogy súlyos probléma az agresszió, és szükséges lenne a dolgozók megfelelő felkészítése az ilyen helyzetek megoldására [20]. Ezt támasztja alá a saját vizsgálatunk eredménye is, amely szerint az agresszió a legnehezebben kezelhető ápolási feladat. A mentésben és a sürgősségi ellátásban dolgozók markáns véleményt fogalmaztak meg a szerfogyasztó személyek ellátásáról is. A szerfogyasztók sürgősségi ellátása kapcsán az agresszió reális kockázatával kell számolni. A betegek emberi méltóságának és személyiségi jogainak tiszteletben tartására különös gonddal kell ügyelni akkor is, ha esetenként elkerülhetetlen a kényszerintézkedés [21]. Egy dietetikus hallgatók körében végzett felmérés is a mentális betegségek mélyrehatóbb oktatásának szükségességét és az erre irányuló hallgatói igényt állapította meg, a táplálkozászavarokhoz kapcsolódó ismeretek tükrében [22]. A főiskolai ápolóképzésben ugyanakkor pozitív kezdeményezés a Semmelweis Egyetem Egészségtudományi Karának Ápolástan Tanszékén a pszichiátria tantárgy oktatási struktúrájába épített, érzékenyítést is jelentő óra. A hallgatók részéről igen kedvező fogadtatása van a főbb mentális betegségek tapasztalati szakértőkkel közös bemutatásának. A szkizofrénia betegséggel kapcsolatban hatékonyabb oktatási módszerek iránti igényre mutat rá vizsgálatunk azon eredménye, hogy magasan a szkizofréniát nevezték meg a legtöbben a betegségek súlyosság szerinti besorolásakor. Mindazonáltal meglátásunk szerint az akut ellátásban dolgozó ápolók számára a pszichiátria területe nehezen egyeztethetö össze a sürgősség, az akut életveszély fogalmakkal. A balesettől vérző, erős fájdalmat jelző ember szenvedése látványos, a pszichózistól szenvedő ember kínzó gondolatai, a depresszióban lévő ember gyötrődése, belső vívódásai viszont kevésbé szembetűnők. Kéri szerint már gyerekkorban kialakul az a betegségfogalom, hogy aki lázas vagy köhög, az beteg, ami fáj, vérzik, az a betegség. Úgy véli, hogy erősen rögzülnek betegségjelzőként ezek a fizikai szinten jelentkező tünetek, és csak később tanuljuk meg, hogy társadalmunk betegségnek tekinti a belső lelki folyamatok, a vágyak, érzelmek, gondolatok szélsőséges és tartós eltéréseit is. Önkéntelenül is tartózkodást, félelmet és elkerülést vált ki a hallucinációkkal magában tár- 
salgó, furcsa, eksztatikusan viselkedő vagy visszahúzódó ember látványa. Ezzel szemben egy fájdalmaktól szenvedő, sérült, legyengült ember együttérzést, empátiát hív életre, hiszen esetében kétségkívül betegségről van szó [23]. A kulcs tehát a fejlesztésben, az ismeretek elsajátításában, vagyis az oktatásban van. Az eredmények azt mutatják, hogy az ápolók nagy része nem hisz a mentális betegek felépülésében, a pszichiátriai ápolók többsége sem. A felépülési modell (recovery model) nem a teljes gyógyulást tűzi ki célul, hanem egy reményteli, kielégítő életminőség elérését és az elérhető legönállóbb életvezetést, akár meglévő tünetek mellett [24]. Az ápolóképzések ugyanakkor a hagyományos klinikai megközelítéssel összhangban a tünetek megszüntetésére helyezik a hangsúlyt. A vártnál pozitívabb viszonyulást mutattak viszont az ápolók a nagy létszámú pszichiátriai szociális intézményekből a közösségbe kitagolt mentális betegekre vonatkozó kérdésnél. Ez azért fontos, mert a megkezdett „férőhelykiváltás” a 2014-2020-as pénzügyi ciklusban az EU támogatásával folytatódik. Három európai uniós projekt is folyamatban van (EFOP-2.2.2-16, VEKOP-6.3.2-17, EFOP-2.2.5-17), amely az évtizedekkel ezelőtt, fóként kastélyokban kialakított pszichiátriai otthonokból „visszahozza” a betegeket a társadalomba [5]. Ők az egészségügyi rendszer minden szintjén megjelennek majd, ezért is van kiemelt jelentősége az előítéletektől, a kirekesztő törekvésektől mentes, elfogadó, nyitott dolgozói attitűdnek.

\section{Következtetések}

Bár a biopszichoszociális modell fogalma régóta jelen van az egészségügyi képzések elméleti ismeretanyagában, a mentális betegségek jobb megértéséhez, a betegek humanisztikus, egyenlő bánásmódot nyújtó ápolásához és a mentális zavarban szenvedő emberek előítéletek nélküli elfogadásához szükséges az oktatás érzékenyítést is tartalmazó módszertani reformja. A sorstárs/tapasztalati szakértők bevonása a képzésekbe, a szenvedés- és felépüléstörténetek megismerése, az elméleti órákhoz kapcsolt őszinte, személyes hangvételü beszélgetés betegekkel vagy a közösségi pszichiátrián töltött gyakorlat mind olyan elemek, amelyekkel pozitív eredmények érhetők el a mentális betegekkel szembeni szemléletváltás terén. Egy világszintű népbetegséggel, a depresszióval is foglalkozó pszichiátriának a kisklinikumi szint fölé kell emelkednie az oktatásban. Célszerü lenne a témát szakmai diskurzus tárgyává tenni. Ennek szükségességét megerősíti az a részvételi aktivitásból levont következtetésünk is, mely szerint a mentális betegségekkel kapcsolatos téma, fontossága ellenére, vagy nem ragadja meg a szakdolgozók nagy részének érdeklődését, vagy a hozzá kapcsolódó negatív érzések miatt a szakdolgozók hárítják az együttmúködést. Ennek hátterében olyan okok lehetnek, amelyek feltárására, az anonim kérdőíves módszert mellőzve, további, mélyebbre hatoló vizsgálatokat tartunk szükségesnek.
Anyagi támogatás: A közlemény megírása anyagi támogatásban nem részesült.

Szerzői munkamegosztás: Á. A.: A vizsgálat megtervezése, a mérőeszköz elkészítése, az engedélyek beszerzése, irodalomkutatás, az adatbázis kezelése, statisztikai elemzés, a kézirat szövegezése. B. Z.: A vizsgálat tervezése, irányítása, engedélyek beszerzése, a kézirat szakmai kontrollja. M. J.: A kézirat szakmai véleményezése. A cikk végleges változatát valamennyi szerző elolvasta és jóváhagyta.

Érdekeltségek: A szerzőknek nincsenek érdekeltségeik.

\section{Köszönetnyilvánítás}

Köszönettel tartozunk a MESZK tagozatvezetőinek és azoknak a vezető ápolási szakembereknek, akik a kérdőívet terjesztették, valamint a kutatásban részt vevő minden egészségügyi szakdolgozónak a kitöltésért.

\section{Irodalom}

[1] Scull A. (ed.) The cultural history of madness. [Az örület kultúrtörténete.] Corvina Kiadó, Budapest, 2017. [Hungarian]

[2] Sztancsik V, Máth J, Pék Gy. Stigmatization of psychiatric patients and schizophrenic people in Hungary. In: Angyalosi G, Münnich Á, Pusztai G. (eds.) Interdisciplinary research in humanities. Constantine the Philosopher University in Nitra, Faculty of Central European Studies, Nitra, 2013; pp. 297-310.

[3] Nieradzik K, Cochrane R. Public attitudes towards mental illness - the effects of behaviour, roles and psychiatric labels. Int J Soc Psychiatry 1985; 31: 23-33.

[4] Buchman-Wildbaum T, Paksi B, Sebestyén E, et al. Social rejection towards mentally ill people in Hungary between 2001 and 2015: has there been any change? Psychiatry Res. 2018; 267: 73-79.

[5] Ács A, Molnár E, Molnár Gy, et al. The care of people living with mental illness in the Hungarian social care system: the process of deinstitutionalization and the phenomenon of stigmatization. Developments Health Sci. 2019; 2: 1-8.

[6] Stuart H. Violence and mental illness: an overview. World Psychiatry $2003 ; 2$ : 121-124.

[7] Thornicroft G. Shunned: discrimination against people with mental illness. Oxford University Press, New York, NY, 2006.

[8] Zrínyi M, Balogh Z. Professional attitudes and access to health care. [Szakdolgozói attitűdök és az egészségügyi ellátáshoz való hozzáférés.] Nővér 2002; 15(1): 11-17. [Hungarian]

[9] Zrínyi M, Balogh Z. Student nurse attitudes towards homeless clients: a challenge for education and practice. Nurs Ethics 2004; 11: 334-348.

[10] Thornicroft G, Brohan E, Rose D, et al. Global pattern of experienced and anticipated discrimination against people with schizophrenia: a cross-sectional survey. Lancet 2009; 373: 408-415.

[11] Thornicroft G, Rose D, Kassam A. Discrimination in health care against people with mental illness. Int Rev Psychiatry 2007; 19: 113-122.

[12] Lauber C, Nordt C, Braunschweig C, et al. Do mental health professionals stigmatize their patients? Acta Psychiatr Scand. 2006; 113(Suppl 429): 51-59.

[13] Harangozó J, Reneses B, Brohan E, et al. Stigma and discrimination against people with schizophrenia related to medical services. Int J Soc Psychiatry 2014; 60: 359-366.

[14] Ács A. BSc Nursing students' attitude study towards mental health patients. [Mentális zavarban szenvedőkkel szembeni 
attitűdvizsgálat BSc ápoló hallgatók körében.] ÁpolásÜgy 2012; 26(1): 15-18. [Hungarian]

[15] Mészáros J, Balogh Z, Seregi J. Evolution of professional and moral esteem of graduate nurses. [Diplomás ápolók szakmai és erkölcsi megbecsülésének alakulása.] Orvosképzés 2002; 77: 297-301. [Hungarian]

[16] Madianos M, Economou M, Peppou LE, et al. Measuring public attitudes to severe mental illness in Greece: development of a new scale. Eur J Psychiatry 2012; 26: 55-67.

[17] Cohen J, Struening EL. Opinions about mental illness in the personnel of two large mental hospitals. J Abnorm Soc Psychol. 1962; 64: 349-360.

[18] Taylor SM, Dear MJ. Scaling Community Attitudes Toward the Mentally Ill. CAMI SCALE. Available from: https://camiscale. $\mathrm{com} /$ article-scaling-community-attitudes-toward-the-mentallyill/ [accessed: August 27, 2019].

[19] Rigó E. Neurological nursing. In: Kornéth A. (ed.) Small clinical nursing. [Ideggyógyászati szakápolástan. In: Kornéth A. (szerk.) Kisklinikumi szakápolástan.] Medicina Könyvkiadó, Budapest, 2013; pp.15-48. [Hungarian]

[20] Irinyi T, Németh A, Lampek K. Violence against health care providers and its correlations with sociodemographic and workplace-related factors. [Az egészségügyi szakdolgozókat ért agresszív cselekmények kapcsolata szociodemográfiai és munka- helyi tényezőkkel.] Orv Hetil. 2017; 158: 229-237. [Hungarian]

[21] Tringer L. (ed.) Emergency care in psychiatry. [Sürgősségi ellátás a pszichiátriában.] Medicina Könyvkiadó, Budapest, 2003. [Hungarian]

[22] Ács A, Molnár Sz, Mák E, et al. Survey on the knowledge of dietitians and dietitian students of psychiatric disorders and their attitudes concerning mental patients. [Dietetikusok és dietetikus hallgatók pszichiátriai betegségekre vonatkozó ismereteinek és a mentális zavarban szenvedőkkel kapcsolatos attitüdjének vizsgálata.] Új Diéta 2016; 25(5): 15-18. [Hungarian]

[23] Kéri Sz. The concept and interpretation of psychiatric illness in the light of recent neuroscience research. [A pszichiátriai betegség fogalma és értelmezése az újabb idegtudományi kutatások tükrében.] Magy Tud. 2009; 170: 899-905. Available from: http://www.matud.iif.hu/2009/09aug/02 htm [accessed: August 27, 2019]. [Hungarian]

[24] Bugarszki Zs. A recovery-based approach to mental problems. [A mentális problémák felépülés alapú megközelítése.] Esély 2013; 24(5): 68-85. [Hungarian]

(Ács Andrea, Pomáz, Somogyi-Bacsó u. 7/a, 2013 e-mail: acsandrea@netquality.hu)

"Spina etiam grata est ex qua spectatur rosa."

(Egy tövisbokor is lehet szép, ha benne rózsa virít.

\author{
Az Orvosi Hetilap 2019; 160: 1924. oldalán (48. szám) megjelent OH-kvízre \\ egy helyes megfejtés érkezett. \\ A beküldő: Dr. Bíró László (Budapest). \\ A nyertesnek szívből gratulálunk. \\ Nyereményét - egy, az Akadémiai Kiadó webáruházában \\ kedvezményes vásárlásra jogosító kupont - e-mailen küldjük el.
}

A cikk a Creative Commons Attribution 4.0 International License (https://creativecommons.org/licenses/by/4.0/) feltételei szerint publikált Open Access közlemény, melynek szellemében a cikk bármilyen médiumban szabadon felhasználható, megosztható és újraközölhető, feltéve, hogy az eredeti szerző és a közlés helye, illetve a CC License linkje és az esetlegesen végrehajtott módosítások feltüntetésre kerülnek. (SID_1) 